\section{Saša Šimnovec}

Osnovna šola Vodice

sasa.simnovec@gmail.com
Zbornik povzetkov strokovne konference Spodbujanje učinkovitega učenja, Koper, 26. avgust 2020

Abstracts of the Professional Conference Developing Effective Learning, Koper, 26 August 2020

\section{Vizualne opore učne ure pri učencih $z$ avtističnimi motnjami}

Osnovnošolski učitelji se zaradi težnje po uresničevanju načel inkluzije v razredu srečujemo z raznoliko populacijo učencev. Kljub različnosti si vsi otroci v šolskem prostoru želijo, da bi jih vrstniki sprejeli in da bi bili učno uspešni. Različne situacije znotraj šolskega prostora (senzorni dražljaji, konflikti z vrstniki, zahteve avtoritete in drugo) lahko pri učencih izzovejo vedenjsko neprimerne odzive. Posebni primanjkljaji na področju vedenja so prisotni pri učencih, ki so opredeljeni kot otroci oziroma mladostniki z avtističnimi motnjami. Pri učencih z avtističnimi motnjami so prisotni primanjkljaji na področju socialne komunikacije in interakcije ter na področju aktivnosti, vedenja in interesov. Primanjkljaji so razvrščeni na kontinuumu od lažjih in za okolje manj motečih do težjih, ki so navadno izrazitejši in bolj moteči za učenčevo okolje. Strokovni delavci in učitelji osnovnih šol se redno soočamo z izzivi pri svojem vzgojno-izobraževalnem delu, iščemo načine, metode in strategije, ki bi nam omogočale učinkovitejše delo z otroki in mladostniki, ki so opredeljeni kot učenci $z$ avtističnimi motnjami. $V$ prispevku bodo opisani pristopi, ki nam bodo olajšali delo z omenjeno populacijo. Predstavljen bo primer vizualnih opor pri učni uri (načrtovanje učnih vsebin s pomočjo slikovnega materiala, tabela pričakovanega vedenja), ki posledično pripomorejo k socialno sprejemljivejšim vedenjskim odzivom. Nudenje opore in pomoči učencu $z$ avtističnimi motnjami ter spodbujanje $\mathrm{k}$ celostnemu razvoju pomagata pri doseganju individualne osebne in učne uspešnosti otroka oziroma mladostnika.

Ključne besede: motnje avtističnega spektra, strokovni delavci, vedenjski odkloni, strategije umirjanja, vizualne opore

\section{Visual Support of the Lesson for Students with Autism}

Due to the tendency to implement the principles of inclusion in the classroom, primary school teachers are faced with a diverse population of students. Despite their diversity, all children want to be accepted by their peers and want to be successful learners. Different situations within the school space (sensory stimuli, conflicts with peers, demands of authority, etc.) can provoke behaviourally inappropriate responses in students. Children or adolescents with autism tend to have specific behavioural difficulties. Students with autism often lack social interaction and communication skills which is reflected in activities, behaviour and interests. Different situations can cause a variety of inappropriate behavioural reactions in students. Primary school teachers and other educational professionals are often faced with challenges which require a constant quest in choosing the appropriate methods, strategies, etc., which enable them to cope with learners with autism more effectively. This article presents various general approaches that will empower teachers to become competent in working with the aforementioned group. An example of using visual support in the classroom (planning of learning contents with the help of pictorial material, table of expected behaviour), which contributes to more socially acceptable behavioural responses, will be presented. By providing support and help to students with autism and encouraging them towards wholesome development, these students become more empowered to become more successful in a personal and educational context, their personal success, and success in education.

Key words: autism, educational professionals, behavioural disorders, calming strategies, visual support 